Original Research Paper

\title{
Diversity of Reef Fish in Pancuran Beach and The Harbor Area of Karimunjawa National Park
}

\author{
Dhanis Nuranggitasari ${ }^{1 *} \&$ Ardyan Pramudya Kurniawan ${ }^{1}$ \\ Program Studi Biologi, Fakultas Sains dan Teknologi, Universitas Islam Negeri Sunan Kalijaga, Jalan \\ Marsda Adisucipto, Yogyakarta, 55281, Indonesia
}

\author{
Article History \\ Received : October $06^{\text {th }}, 2021$ \\ Revised : October $17^{\text {th }}, 2021$ \\ Accepted : October 29 $9^{\text {th }}, 2021$ \\ Published : November $08^{\text {th }}, 2021$ \\ *Corresponding Author: \\ Dhanis Nuranggitasari, \\ Program Studi Biologi, Fakultas \\ Sains dan Teknologi, Universitas \\ Islam Negeri Sunan Kalijaga, \\ Kota Yogyakarta, Indonesia \\ Email: dhanis.dna@gmail.com
}

\begin{abstract}
Research on the biodiversity of Ikhthiofauna in coral reef ecosystems in Karimunjawa National Park was carried out in March 2021. This study aimed to study the species of reef fish found in the National Park Karimunjawan, to study the dominant reef fish species, the level of diversity, and the factors that influence reef fish biodiversity in Karimunjawa National Park. Data collection was carried out at two research locations, namely Pancuran Beach and Harbor Pier. This research was conducted using the visual census method at each station made transects with a distance of $5 \mathrm{~m}$ per transect. Each transect is $50 \mathrm{~m}$ long parallel to the shoreline. Observations were made by snorkeling along the $2.5 \mathrm{~m}$ transect line to the right and the left, then the fish obtained were drawn using waterproof paper, numbered per species, and photographed using an underwater camera for identification. Data analysis was carried out, including descriptive analysis to analyze fish characteristics and quantitative analysis to calculate data, including the Shannon Diversity Index ( $\left.\mathrm{H}^{\prime}\right)$, Simpson's Dominance Index (C), and Evenness Index $(\mathrm{E})$. The environmental parameters taken include water temperature, salinity, $\mathrm{pH}$, and DO. This study identified a total of 59 species of reef fish from 17 families, with the dominant family was Pomacentridae. The level of diversity $\left(\mathrm{H}^{\prime}\right)$ at the research location at Pancuran Beach reached 3.392, while at the Harbor Pier, it reached 3.428. The Simpson Dominance Index (C) value at the Pancuran Beach location is 0.044, and the Harbor Pier is 0.047. The Evenness Index (E) value at the Pancuran Beach location is 0.88 , and the Harbor Pier is 0.85 . The difference in the index value is influenced by various environmental factors, both physically, chemically, and biologically.
\end{abstract}

Keywords: Biodiversity, reef fish, coral reef, Pancuran Beach, Harbor Pier

\section{Pendahuluan}

Taman Nasional Karimunjawa merupakan salah satu kawasan konservasi dengan bidang konservasi berbasis kelautan. Taman Nasional Karimunjawa secara geografis terletak pada koordinat $5^{\circ} 40^{\prime} 39^{\prime \prime}-5^{\circ} 55^{\prime} 00^{\prime \prime} \mathrm{LS}$ dan $110^{\circ} 05^{\prime} \quad 57^{\prime \prime}-110^{\circ} 31$ ' 15" BT. Secara administratif Taman Nasional Karimunjawa termasuk ke dalam wilayah Kabupaten Jepara, Jawa Tengah. Taman Nasional Karimunjawa berupa kepulauan yang terbagi menjadi 2 seksi pengelolaan dengan 9 zona (Direktorat KKJI, 2015).
Ikan karang memiliki fungsi yang penting bagi kelangsungan ekosistem terumbu karang. Terumbu karang dan ikan karang memiliki interaksi sebagai penyeimbang ekosistem yang meliputi aktivitas nursery ground, feeding ground, dan spawning ground (Arini, 2013). Menurut Zurba (2019) kondisi fisik terumbu karang yang kompleks memiliki pengaruh terhadap keragaman komposisi ikan karang dan produktivitas biota yang tinggal di dalamnya. Dari data penelitian yang pernah dilakukan diketahui bahwa semakin tinggi tingkat keanekaragaman terumbu karang maka semakin tinggi pula keanekaragaman jenis ikan karang yang ditemukan (Sugianti \& Mujiyanto, 
2013). Berdasarkan kegiatan monitoring yang dilakukan oleh BTN Karimunjawa terjadi penurunan jumlah keanekaragaman ikan. Terjadinya penurunan jumlah keanekaragaman ikan tersebut disebabkan oleh aktivitas masyarakat terhadap produk perikanan dan jasa pariwisata bahari. Sehingga menyebabkan terjadinya pencemaran lingkungan dari aktivitas kapal dan pencemaran oleh pengunjung seperti sampah.

Suryono et al. (2018) menyatakan bahwa kerusakan terumbu karang oleh aktivitas manusia dapat terjadi karena adanya aktivitas penambangan batu karang sebagai bahan bangunan dan wisata bahari yang sering memicu rusaknya terumbu karang akibat terinjak atau tersentuh. Selain itu Yuliana et al. (2017) juga menyatakan rusaknya ekosistem terumbu karang dapat terjadi oleh aktivtas penangkapan ikan yang tidak ramah lingkungan.
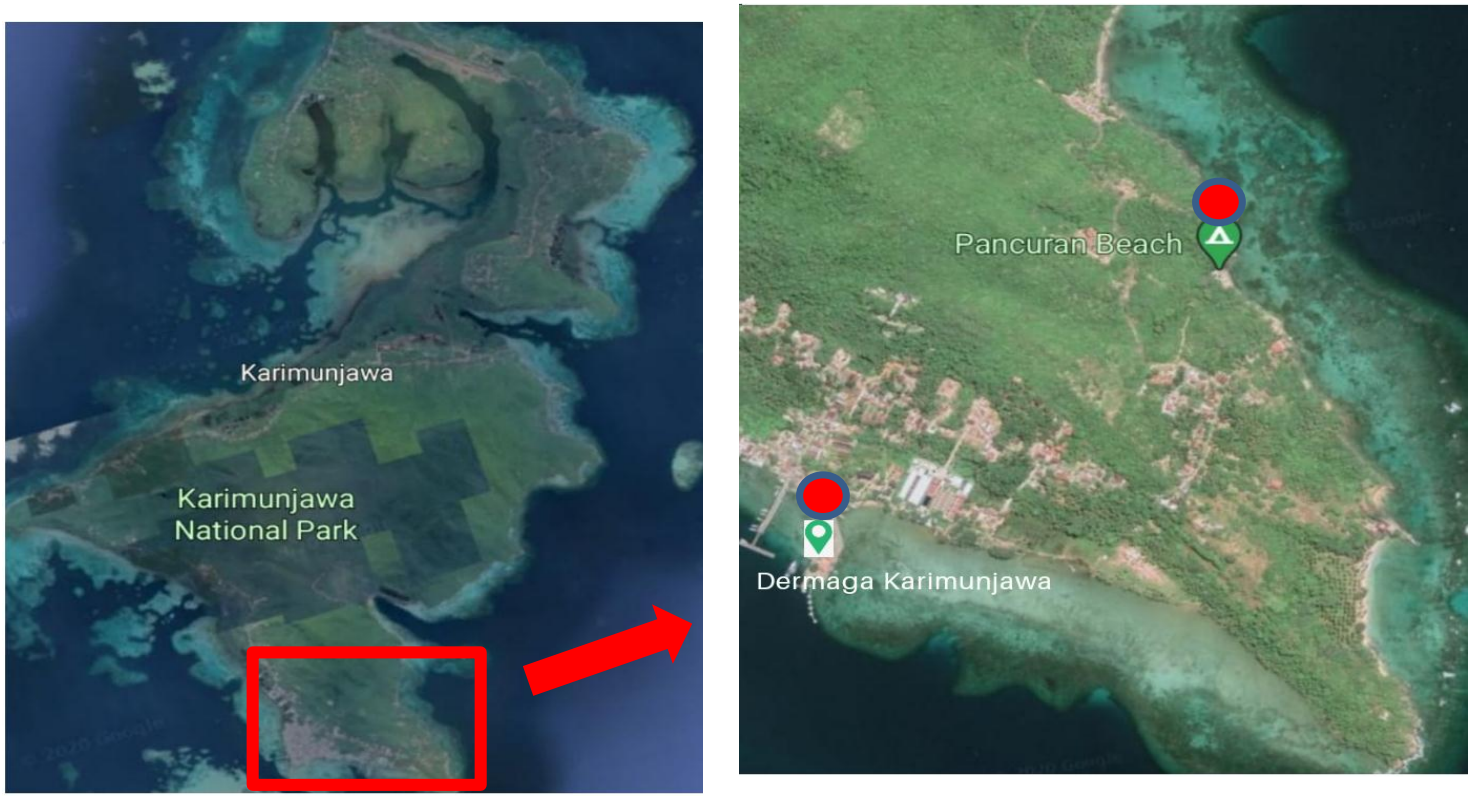

Gambar 1. Lokasi pengambilan data ikan karang di Kawasan Taman Nasional Karimunjawa. a) Pantai Pancuran; b) Dermaga Pelabuhan Karimunjawa

Kegiatan penelitian mengenai keanekaragaman ikan karang penting dilakukan terutama untuk mengkaji pola distribusi organisme yang dapat dicirikan dari kelimpahannya pada masing-masing lokasi. Selain hal itu juga berfungsi untuk menganalisis dampak aktivitas manusia dalam kegiatan konservasi dan penanggulangannya. Atas dasar tersebut maka dilakukan penelitian ini untuk mengetahui bagaimana keanekaragaman ikan perairan Taman Nasional Karimunjawa, sehingga data yang diperoleh dapat dijadikan pedoman upaya pengelolaan dan konservasi sumber daya ikan di daerah tersebut.

\section{Bahan dan metode}

\section{Waktu dan Tempat}

Penelitian dilakukan di Pulau Karimunjawa, Taman Nasional Karimunjawa pada bulan Februari sampai bulan Maret 2021 pada dua stasiun pengamatan yaitu stasiun I Pantai Pancuran dan stasiun II Dermaga Pelabuhan (Gambar 1). Penelitian dilakukan pada pagi hingga siang hari saat air laut surut di kedalaman 3-5 meter. 
digunakan untuk pengambilan gambar ikan. Buku identifikasi untuk memudahkan identifikasi ikan. GPS untuk menentukan titik koordinat, $\mathrm{pH}$ meter untuk mengukur $\mathrm{pH}$, refraktometer untuk mengukur salinitas, dan DO kit untuk mengukur DO.

\section{Metode Pengambilan Data}

Pengambilan data ikan meliputi pengamatan jenis dan jumlah ikan yang dilakukan dalam area pengamatan menggunakan metode visual sensus pada setiap stasiun yang telah dibuat tiga transek dengan jarak $5 \mathrm{~m}$ per-transeknya. Masing-masing transek tersebut sepanjang $50 \mathrm{~m}$ sejajar dengan garis pantai. Pengamatan dilakukan dengan cara snorkling disepanjang garis transek dengan jarak pandang sejauh 2,5 meter ke kanan dan ke kiri. Ikan yang diperoleh di gambar menggunakan kertas tahan air, dihitung jumlah per jenisnya, kemudian difoto menggunakan kamera underwater untuk diidentifikasi. Identifikasi dilakukan dengan cara mencatat karakteristik ikan berdasarkan bentuk tubuh dan warna ikan, dengan cara pengamatan secara langsung, kemudian dicocokkan dengan buku identifikasi dan foto dokumentasi.

\section{Analisis Data}

Analisis data dilakukan dengan analisis deskriptif dan analisis kuantitatif. Analisis deskriptif dalam penelitian ini digunakan untuk menganalisis karakteristik ikan. Sedangkan analisis kuantitatif dalam penelitian ini digunakan untuk perhitungan data menurut Ernst, et al (2002) yang meliputi:

a. Indeks Keanekaramagan jenis ShanonWiener ( $\left.\mathrm{H}^{\prime}\right)$

$\mathrm{H}^{\prime}=-\Sigma\left[\right.$ pi $\ln ($ pi) $]$ dimana pi $: \frac{n i}{N}$

Keterangan:

H': Indeks Keanekaragaman jenis

Ni: Jumlah individu suatu jenis

$\mathrm{N}$ : Jumlah seluruh jenis
Kriteria penentuan Indeks Keanekaragaman Jenis Shanon-Wiener ( $\left.\mathrm{H}^{\prime}\right)$ :

$\mathrm{H}^{\prime}>3$ keanekaragaman jenis tinggi

H' 1-3 keanekaragaman jenis sedang

$\mathrm{H}^{\prime}<1$ keanekaragaman jenisnya rendah

b. Indeks Evenness (E)

$\mathrm{E}=\frac{H^{\prime}}{\operatorname{Ln} S}$

Keterangan:

E : Indeks Evenness

H': Indeks keanekaragaman jenis

$\mathrm{S}$ : Jumlah spesies

Kriteria Penentuan Indeks Evenness (E):

$\mathrm{E}=0$ sangat tidak merata

$\mathrm{E}=1$ kelimpahan sama (merata)

c. Indeks Dominansi (C)

$\mathrm{C}=\Sigma[\mathrm{ni} / \mathrm{N}]^{2}$

Keterangan:

$\mathrm{C}$ : Indeks dominansi suatu jenis

ni: jumlah individu suatu jenis

$\mathrm{N}$ : Jumlah individu seluruh jenis

Kriteria Penentuan Indeks Dominansi $(\mathrm{C})$ :

$0<\mathrm{C} \leq 0,5 \quad$ : Dominansi rendah

$0,5<\mathrm{C} \leq 0,75$ : Dominansi sedang

$0,75<\mathrm{C} \leq \quad$ : Dominansi tinggi

\section{Hasil dan Pembahasan}

\section{Data Spesies Ikan Karang}

Berdasarkan hasil penelitian yang dilakukan pada dua stasiun yaitu Pantai Pancuran dan Dermaga Pelabuhan pada bulan FebruariMaret 2021 diketahui famili dengan jumlah spesies ikan yang tinggi berasal dari famili Pomacentridae, Labridae, Nemipteridae, Apogonidae, dan Gobiidae. Gambar 2 berikut ini adalah grafik jumlah data spesies ikan karang berdasarkan familinya. 


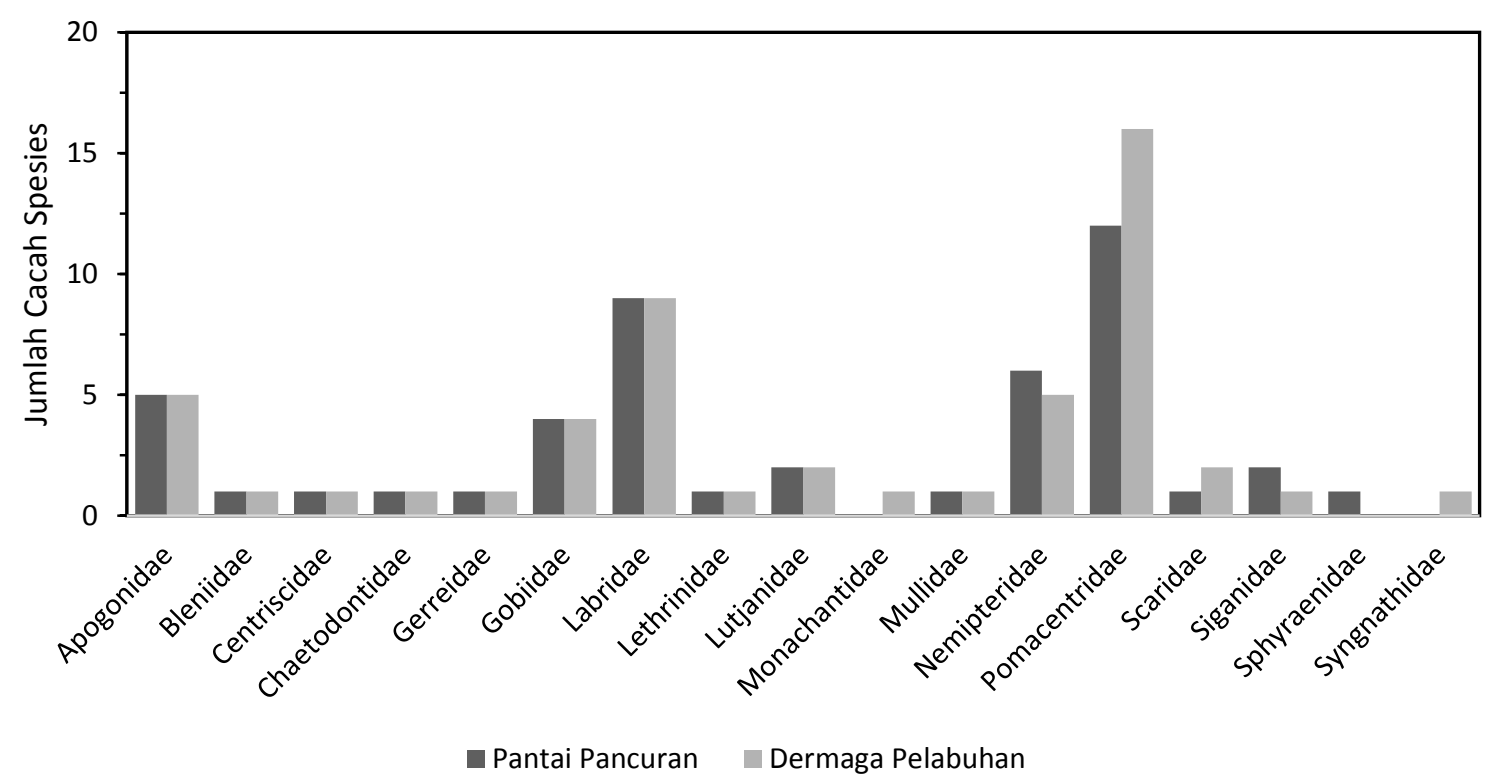

Gambar 2. Jumlah cacah spesies ikan karang setiap famili pada lokasi penelitian di Pantai Pancuran dan Dermaga Pelabuhan Karimunjawa

Berdasarkan hasil penelitian yang telah dilakukan ditemukan total 17 famili ikan karang pada kedua lokasi penelitian yaitu famili Apogonidae, Bleniidae, Centriscidae, Chaetodontidae, Gerreidae, Gobiidae, Labridae, Lethrinidae, Lutjanidae, Monachantidae, Mullidae, Nemipteridae, Pomacentridae, Scaridae, Siganidae, Sphyraenidae, dan Syngnathidae. Jumlah famili ikan karang pada Pantai Pancuran sebanyak 15 famili yang terdiri dari famili Apogonidae, Bleniidae, Centriscidae, Chaetodontidae, Gerreidae, Gobiidae, Labridae, Lethrinidae, Lutjanidae, Muliidae, Nemipteridae, Pomacentridae, Siganidae, Scaridae, dan Sphyraenidae. Sedangkan pada Dermaga Pelabuhan diperoleh 16 famili ikan karang diantaranya famili Apogonidae, Bleniidae, Centriscidae, Chaetodontidae, Gerreidae, Gobiidae, Labridae, Lethrinidae, Lutjanidae, Monachantidae, Mullidae, Nemipteridae, Pomacentridae, Siganidae, Scaridae, dan Syngnathidae.

Adapun famili yang memiliki spesies ikan karang terbanyak adalah Pomacentridae dengan jumlah 12 spesies pada Pantai Pancuran dan 16 spesies pada Dermaga Pelabuhan. Spesies ikan karang yang termasuk dalam famili Pomacentridae pada kedua lokasi pengamatan terdiri dari jenis Abudefdufvaigiensis, Abudefduf sexfasciatus, Abudefduf lorenzi, Dischistodus melanotus, Dischistodus perspiclliatus, Dischistodus crhrysopoecilus, Hemiglyphidodon plagiometapon, Pomacentrus adelus, Pomacentrus simsiang, P. moluccensis, P. vaiuli, $P$. albifasciatus, $P$. chrysurus, Stegastes albifasciatus, $P$. prosopotaenia, dan $P$. philippinus, P. wardi.

Berdasarkan hasil penelitian secara keseluruhan ditemukan total 59 spesies ikan karang yaitu sebanyak 47 spesies pada lokasi Pantai Pancuran dan 52 spesies pada lokasi Dermaga Pelabuhan (Gambar 3). Pada kedua lokasi penelitian tersebut terdapat 5 spesies ikan karang yang kehadirannya memiliki jumlah yang tinggi yaitu spesies Halichoeres richmondi (Pantai Pancuran 63 cacah individu/750m²; Dermaga Pelabuhan 60 cacah individu $/ 750 \mathrm{~m}^{2}$, Siganus virgattus (Pantai Pancuran 35 cacah individu $/ 750 \mathrm{~m}^{2}$; Dermaga Pelabuhan 45 cacah individu $/ 750 \mathrm{~m}^{2}$ ), Istigobius rigilus (Pantai Pancuran 46 cacah individu $/ 750 \mathrm{~m}^{2}$; Dermaga Pelabuhan $30 \quad 46$ cacah individu $/ 750 \mathrm{~m}^{2}$ ), Pentapodus triviattatus (Pantai Pancuran 31 cacah individu $/ 750 \mathrm{~m}^{2}$; Dermaga Pelabuhan 34 cacah individu $/ 750 \mathrm{~m}^{2}$ ), dan Choerodon ancorago (Pantai Pancuran 32 cacah individu $/ 750 \mathrm{~m}^{2}$; Dermaga Pelabuhan 30 cacah individu $/ 750 \mathrm{~m}^{2}$ ). 


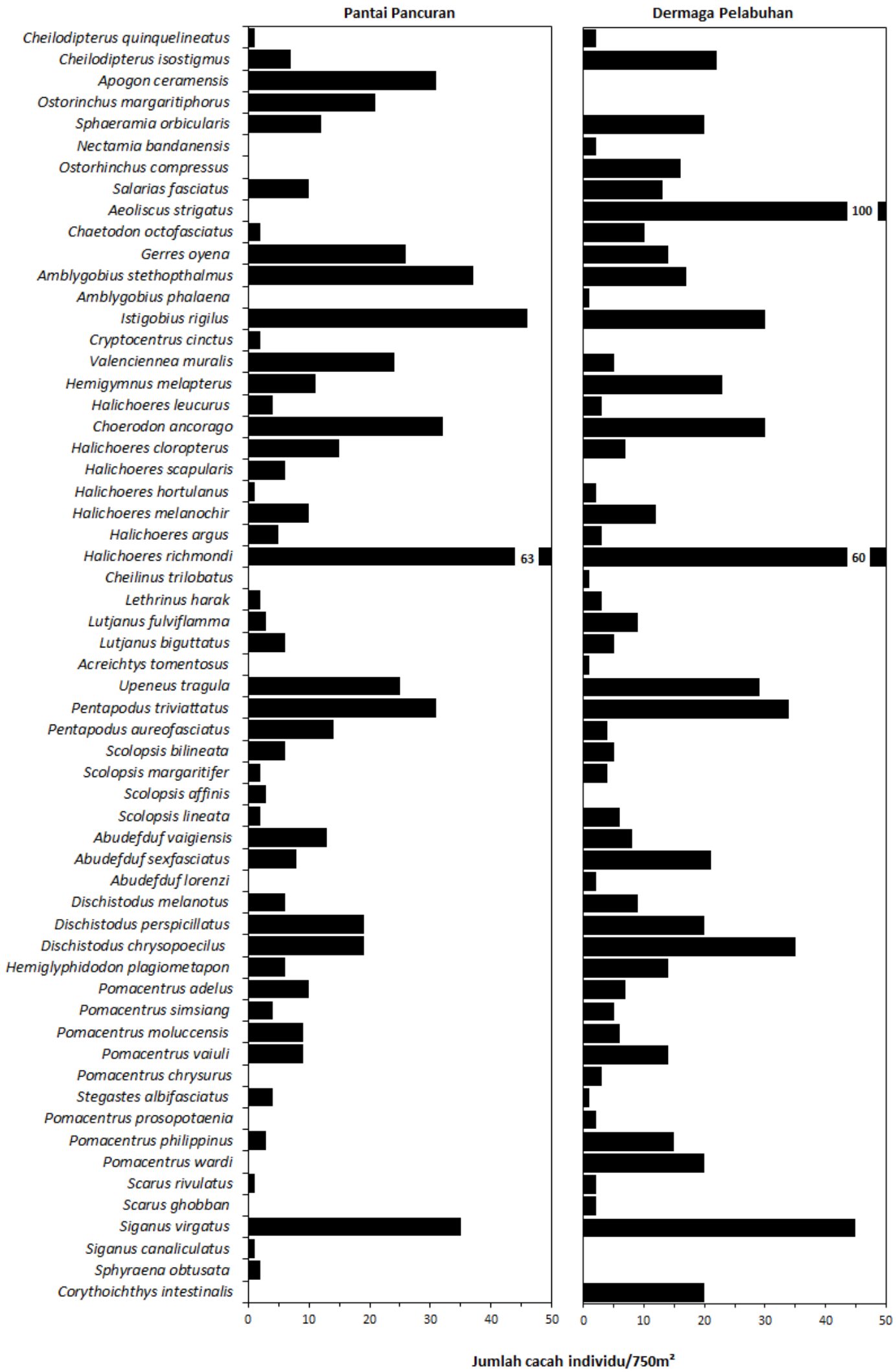

Gambar 3. Spesies ikan karang yang ditemukan pada lokasi penelitian di Pantai Pancuran dan Dermaga Pelabuhan 
Terdapat satu spesies ikan karang yang memiliki jumlah cacah individu tinggi namun kehadirannya hanya dijumpai pada satu lokasi pengamatan pada Dermaga Pelabuhan dan tidak dijumpai pada lokasi Pantai Pancuran yaitu jenis Aeoliscus strigatus (100 cacah individu/750m²) yang berasal dari famili Centriscidae.

Aeoliscus strigatus memiliki warna yang dapat bervariasi sesuai dengan jenis habitatnya, umumnya berwarna kuning kehijauan dengan garis menyebar pada saat berada di habitat lamun dan berwarna pucat dengan garis hitam saat berada di habitat substrat terbuka dengan pasir putih. Ikan ini hidup secara berkelompok pada range kedalaman 2-42 m, memangsa krustasea kecil dan zooplankton. Tubuhnya terbungkus dinding transparan dan berenang sangat unik dengan moncong mengarah ke bawah dan posisi tubuh vertikal sebagai bentuk adaptasi untuk bersembunyi. Aeoliscus strigatus dikenal juga sebagai razorfish atau udang karang (Myers, 1991).

\section{Nilai Indeks Keanekaragaman, Evenness, dan Dominansi}

Apabila dibandingkan antara lokasi Pantai Pancuran dan Dermaga Pelabuhan dapat dikatakan bahwa Dermaga Pelabuhan memiliki jumlah spesies dan famili ikan karang yang relatif lebih tinggi. Hal tersebut dapat dilihat pada hasil nilai indeks keanekaragaman $\left(\mathrm{H}^{\prime}\right)$, indeks evenness (E), dan indeks dominansi (C) yang disajikan pada Tabel 1. berikut:

Tabel 1. Nilai Indeks Keanekaragaman (H'), Indeks Evenness (E), dan Indeks Dominansi (C) di Pantai Pancuran dan Dermaga Pelabuhan Karimunjawa

\begin{tabular}{lrrrrr}
\hline \multicolumn{1}{c}{ Stasiun } & $\begin{array}{c}\text { Jumlah } \\
\text { Spesies }\end{array}$ & $\begin{array}{c}\text { Indeks } \\
\text { Keanekaragaman } \\
\left(\mathbf{H}^{\prime}\right)\end{array}$ & $\begin{array}{c}\text { Indeks } \\
\text { Evenness (E) }\end{array}$ & $\begin{array}{c}\text { Indeks } \\
\text { Dominansi (C) }\end{array}$ & $\begin{array}{c}\text { Cacah } \\
\text { Individu/750m }{ }^{2}\end{array}$ \\
\hline Pantai Pancuran & 47 & 3,392 & 0,881 & 0,44 & 609 \\
$\begin{array}{l}\text { Dermaga } \\
\text { Pelabuhan } \\
\text { Karimunjawa }\end{array}$ & 52 & 3,428 & 0,859 & 0,47 & 744 \\
\hline
\end{tabular}

Berdasarkan tabel diatas diketahui nilai indeks keanekaragaman $\left(\mathrm{H}^{\prime}\right)$ pada Pantai Pancuran dan Dermaga Pelabuhan memiliki nilai indeks $\mathrm{H}^{\prime}>$ 3 sehingga menunjukkan tingkat keanekaragaman yang tinggi. Bila dibandingkan antara Pantai Pancuran dan Dermaga Pelabuhan dapat diketahui bahwa nilai H' pada Dermaga Pelabuhan memiliki hasil yang lebih besar dibandingkan dengan stasiun 2 pada Pantai Pancuran.

Nilai Indeks Evenness (E) pada kedua lokasi mendekati angka 1 yang menunjukkan bahwa hampir seluruh spesies mempunyai kelimpahan yang sama. Sedangkan nilai Indeks Dominansi (C) pada kedua lokasi menunjukkan hasil nilai indeks $0<\mathrm{C} \leq 0,5$ yang berarti dominansi rendah. Hal tersebut mengindikasikan bahwa hampir tidak ada spesies yang mendominasi sehingga keseragaman besar. Perbedaan nilai indeks tersebut disebabkan oleh berbagai faktor, salah satunya adalah kondisi habitat dan terumbu karang. Stasiun 1 memiliki kondisi habitat berupa padang lamun dengan substrat berpasir pada titik awal transek dan pada titik tengah sampai akhir transek ditemukan banyak terumbu karang yang kaya akan alga, puing-puing terumbu serta pecahan coral. Adapun terumbu karang yang sering dijumpai pada stasiun 1 adalah genus Favia dari famili Faviidae.

Menurut Suharsono (2017) genus Favia memiliki koralit berbentuk cenderung bulat plocoid dengan tunas intratentakuler. dan merupakan jenis terumbu karang dengan koloni padat. Genus ini memiliki septa yang berkembang dengan baik. Terumbu karang ini berperan sebagai perlindungan dan merupakan tempat mencari makan atau feeding ground bagi ikan karang.

Selain itu juga ditemukan terumbu karang genus Favites dari famili Faviidae. Genus ini terdiri dari koloni padat yang berbentuk membulat dengan ukuran yang relatif besar. 
Koralit dari genus ini berbentuk cerioid dengan pertunasan intratentakuler berbentuk poligonal dan septa berkembang dengan baik (Suharsono, 2017).

Sementara itu pada Dermaga Pelabuhan memiliki kondisi habitat terumbu karang yang jauh lebih kompleks dan bervariasi, diantaranya genus Acropora, Favia, Favites, dan Porites. Hal tersebut berpengaruh dengan keanekaragaman jenis ikan karang. Menurut Suryo (2013) mengatakan bahwa berdasarkan penelitian yang pernah dilakukan di Taman Nasional Karimunjawa pada ekosistem terumbu karang menunjukkan semakin tinggi tingkat keanekaragaman terumbu karang maka semakin tinggi pula tingkat keanekaragaman jenis ikan karang.

Senada dengan hal tersebut Allen et al, (2015) juga menyatakan bahwa ikan karang akan berasosiasi terhadap kondisi habitat yang akan mempengaruhi keragaman dan distribusinya. Sehingga dapat diketahui bahwa besarnya variasi terumbu karang sangat mempengaruhi variasi ikan karang. Asosiasi antara terumbu karang dan biota laut antara lain spawning ground atau tempat pemijahan, nursery ground (daerah asuhan), dan feeding (tempat mencari makan). Salah satu contohnya adalah ikan karang yang termasuk dalam tipe penggerogot (grazer) dari famili Scaridae, serta biota laut pemakan karang (predator) seperti moluska, bulu babi, ketam kelapa, dan berbagai jenis ikan lainnya (Zurba, 2019).

Selain itu menurut Zurba (2019) terdapat kompetitor terumbu karang dalam memperoleh substrat yang dapat menghambat proses pertumbuhan karang yaitu jenis alga dimana pada Pantai Pancuran dijumpai lebih banyak jenis alga dibandingkan pada Dermaga Pelabuhan sehingga menyebabkan terumbu karang pada Pantai Pancuran lebih sedikit dan tingkat keanekaragaman ikan karang memiliki selisih lebih rendah dibandingkan pada Dermaga Pelabuhan.

\section{Parameter Lingkungan}

Parameter lingkungan yang diukur pada penelitian ini meliputi parameter fisika yaitu pengukuran $\mathrm{pH}$ air, suhu air dan salinitas, serta parameter kimia yaitu pengukuran kadar oksigen terlarut (DO). Hasil pengukuran parameter fisika dan kimia pada kedua lokasi penelitian tersaji pada Tabel 2. berikut:

Tabel 2. Hasil Pengukuran Parameter Lingkungan

\begin{tabular}{lcc}
\hline \multicolumn{1}{c}{ Parameter } & \multicolumn{2}{c}{ Rata-Rata Hasil Pengukuran } \\
\cline { 2 - 3 } & $\begin{array}{c}\text { Pantai } \\
\text { Pancuran }\end{array}$ & $\begin{array}{c}\text { Dermaga } \\
\text { Pelabuhan } \\
\text { Karimun } \\
\text { Jawa }\end{array}$ \\
\hline pH Air & $8,3 \pm 0,07$ & $8,5 \pm 0,07$ \\
\hline Suhu Air $\left({ }^{\circ} \mathbf{C}\right)$ & $30,6 \pm 0,23$ & $31 \pm 0,23$ \\
\hline Salinitas (\%o) & $29,6 \pm 0,95$ & $31 \pm 0,95$ \\
\hline DO (mg/l) & $5,03 \pm 0,62$ & $5,9 \pm 0,62$ \\
\hline
\end{tabular}

a. Derajat Keasaman (pH)

Derajat keasaman $(\mathrm{pH})$ merupakan salah satu indikator kualitas air laut. Berdasarkan Keputusan Menteri Lingkungan Hidup, (2004) tentang baku mutu air laut untuk biota laut yakni dalam kisaran $\mathrm{pH}$ 7,0-8,5.

Senada dengan hal tersebut, Barus et. al (2018) juga menyatakan bahwa nilai $\mathrm{pH}$ yang umum pada wilayah perairan Indonesia berkisar antara 7,0-8,5. Effendi (2003), juga menambahkan derajat keasaman $(\mathrm{pH})$ yang optimal untuk pertumbuhan dan kelangsungan hidup biota laut yaitu 7,0-8,5. Sehingga dapat dikatakan bahwa nilai $\mathrm{pH}$ pada kedua stasiun penelitian masih dalam batas aman dan potensial bagi kehidupan biota laut.

Nilai $\mathrm{pH}$ air laut yang terlalu basa atau asam dapat mengganggu proses metabolisme biota laut sehingga membahayakan keberlangsungan hidup biota laut didalamnya. Besarnya $\mathrm{pH}$ pada suatu perairan dapat dipengaruhi oleh berbagai faktor seperti aktivitas fotosintesis biota laut, aliran dari darat, dan curah hujan (Edward \& Tarigan, 2003).

b. Suhu

Suhu air laut memberi pengaruh yang sangat besar bagi pertumbuhan dan perkembangan biota laut. Suhu yang optimal bagi perkembangan terumbu karang berkisar antara $25^{\circ} \mathrm{C}-29^{\circ} \mathrm{C}$, dengan batas minimum $16^{\circ} \mathrm{C}-17^{\circ} \mathrm{C}$ dan suhu maksimal yang dapat ditolerir berkisar antara $36^{\circ} \mathrm{C}-40^{\circ} \mathrm{C}$ (Zurba, 2019).

Berdasarkan baku mutu air laut untuk biota laut oleh Keputusan Kementerian Lingkungan Hidup No.51 Tahun 2004 
menyatakan bahwa suhu potensial air laut berkisar antara $28^{\circ} \mathrm{C}-30^{\circ} \mathrm{C}$, diperbolehkan terjadi perubahan sampai dengan $<2^{\circ} \mathrm{C}$ dari suhu alami. Sehingga dapat dikatakan suhu pada kedua stasiun penelitian masih dalam batas aman bagi kehidupan biota laut.

\section{c. Salinitas}

Salinitas merupakan salah satu indikator pembatas bagi kehidupan terumbu karang. Salinitas yang optimum bagi kehidupan biota karang berkisar antara 30-33\%. Sedangkan untuk pertumbuan karang yaitu berkisar antara 32-35\%o (Zurba, 2019).

Berdasarkan baku mutu air laut oleh Kementerian Lingkungan Hidup tahun 2004 menyatakan bahwa kadar salinitas yang aman bagi kelangsungan hidup biota laut berkisar antara 33-34\%, diperbolehkan terjadi perubahan sampai $<5 \%$ salinitas rata-rata musiman.

Nilai salinitas pada kedua stasiun penelitian masih dikatakan aman bagi kelangsungan hidup biota laut, namun pada stasiun 1 sedikit lebih rendah dari kadar salinitas optimum. Rendahnya nilai salinitas tersebut dipengaruhi oleh berbagai faktor diantaranya adalah penguapan, gerakan massa air pada daerah pasang surut, dan curah hujan (Nontji, 2002). Selain itu, Mustofa \& Mulyo (2020), juga menyatakan bahwa salinitas air laut dapat dipengaruhi oleh gelombang air laut yang tinggi akibat tiupan angin pada saat melakukan penelitian.

\section{d. Dissolved Oxygen (DO)}

Dissolved oxygen atau oksigen terlarut adalah jumlah total oksigen yang terlarut dalam air. Berdasarkan baku mutu air laut oleh KLH tahun 2004 menyatakan bahwa batas aman oksigen terlarut yaitu $>5 \mathrm{mg} / \mathrm{l}$. Nilai oksigen terlarut dalam air dapat dijadikan sebagai salah satu indikator pencemaran lingkungan dimana nilai DO pada $5 \mathrm{mg} / \mathrm{l}$ tergolong mengalami pencemaran tingkat rendah (Salmin, 2005).

Perairan yang tercemar oleh limbah dapat mengakibatkan rendanya nilai oksigen terlarut dalam air. Hal tersebut terjadi akibat oksigen digunakan oleh mikroorganisme untuk proses pemecahan molekul bahan organik. Selain itu rendahnya kadar oksigen dalam air laut juga dipengaruhi oleh suhu, salinitas, turbulensi air, dan tekanan atmosfer (Effendie, 2003).

\section{Kesimpulan}

Berdasarkan hasil penelitian dapat disimpulkan bahwa dari kedua stasiun penelitian diperoleh 59 jenis ikan karang dari total 17 famili dan famili dengan jumlah spesies terbanyak yakni Pomacentridae. Hasil perhitungan H' pada kedua stasiun penelitian memiliki tingkat keanekaragaman jenis yang tinggi dengan nilai $\mathrm{H}^{\prime}>3$. Sedangkan indeks dominansi pada kedua stasiun adalah mendekati 1 sehingga menunjukkan tidak adanya spesies yang mendominasi. Hasil pengukuran parameter lingkungan berupa $\mathrm{pH}$, suhu, salinitas dan DO menunjukkan bahwa perairan pada kedua stasiun penelitian masih dalam batas aman dan potensial bagi kehidupan biota laut.

\section{Ucapan Terima kasih}

Penulis mengucapkan terimakasih yang sebesar-besarnya kepada Balai Taman Nasional Karimunjawa yang telah memberikan izin sehingga penulis dapat melakukan penelitian di Balai TN Karimunjawa. Terimakasih kepada Bapak Kristiawan, Bapak Warsono dan Bapak Zainuddin selaku pembimbing lapangan, rekan tim lapangan Siti Lathifah Maulany yang telah membantu proses pengambilan data sehingga dapat terwujudnya penulisan ini.

\section{Referensi}

Allen, G.R, R. Steene, P. \& Human, N. D. (2015). Fish Reef Identifiication: Tropical Pasific (2nd), New Word Publications. Singapore. ISBN: 9781878348609.457 p.

Arini, D. I. D. (2013). Potensi Terumbu Karang Indonesia "Tantangan dan Upaya Konservasinya". Balai Penelitian Kehutanan Manado. Manado.

Barus, B. S., Prartono, T., \& Soedarma D. (2018). Pengaruh Lingkungan Terhadap Bentuk Pertumbuhan Terumbu Karang di Perairan Teluk Lampung. Jurnal Ilmu dan Teknologi Kelautan Tropis, 10 (3): 699709.

DOI: https://doi.org/10.29244/jitkt.v10i3.21516

Direktorat KKJI. (2015). Profil Kawasan 
Konservasi Provinsi Jawa Tengah. Jakarta Pusat: Kementerian Kelautan dan Perikanan. http://kkji.kp3k.kkp.go.id/ (Accessed on September 22, 2021).

Edward dan Tarigan Z. (2003). Pemantauan Kondisi Hidrologi di Perairan Raha P. Muna Sulawesi Tenggara dalam Kaitannya dengan Kondisi Terumbu Karang. Makara Sains,7(2): 73-82. DOI: https://doi/org/10.7454/mss.v7i2.330.

Effendie, H. (2003). Telaah Kualitas Air Bagi Pengelolaan Sumber Daya dan Lingkungan Perairan. Kanisius. Yogyakarta.

Ernst, D. S., Ewin, B., \& Klaus, M. H. (2002). Plant Ecology. Karl-Heinz Winter, Heidelberg. Germany.

Kementerian Lingkungan Hidup. (2004). Keputusan Menteri Negara Lingkungan Hidup No. 51 Tahun 2004 Tentang Baku Mutu Air Laut Untuk Biota Laut. Jakarta.

Mustofa A., Mulyo H. (2020). Analisis Pola Sebaran Parameter Fisika Air Laut sebagai Daya Dukung Usaha Budidaya Tambak Ikan di Kabupaten Jepara, Jawa Tengah. Jurnal Enggano, 5 (1): 40-52. DOI: https://doi.org/10.31186/jenggano.5.1.40$\underline{52}$.

Myers, R. F. (1991). Micronesian reef fishes. Second Ed. Coral Graphics, Barrigada, Guam. ISBN: 9780962156427. 298 p.

Nontji, A. (2002). Laut Nusantara. Djambatan. Jakarta.
Salmin (2005). Oksigen Terlarut (DO) dan Kebutuhan Oksigen Biologi (BOD) Sebagai Salah Satu Indikator untuk Menentukan Kualitas Perairan. Oseana 30 (3):21-26. http://oseanografi.lipi.go.id/dokumen/ose ana_xxx(3)21-26.pdf.

Sugianti, Y. \& Mujiyanto. (2013). Biodiversitas ikan karang di perairan Taman Nasional Karimunjawa, Jepara. BAWAL. Widya Riset Perikanan Tangkap 5 (1): 23-31. DOI: http://dx.doi.org/10.15578/bawal.5.1.201 3.23-31.

Suharsono. (2017). Jenis-jenis Karang di Indonesia Edisi 3. LIPI. Jakarta.

Suryono, Wibowo, E., Ario, R., Taufik, N., \& Nuraini, R. A. T. (2018). Kondisi Terumbu Karang di Perairan Pantai Empu Rancak, Mlonggo, Kabupaten Jepara. Jurnal Kelautan Tropis 21 (1): 49-54. DOI: https://doi.org/10.14710/jkt.v21i1.2301.

Yuliana, E., M. Boer., A. Fahrudin, \& M.M. Kamal. (2017). Biodiversity of reef fishes in marine protected area of Karimunjawa National Park. Jurnal Ilmu dan Teknologi Kelautan Tropis, 9 (1): 29-43. DOI: https://doi.org/10.29244/jitkt.v9i1.17915.

Zurba, N. (2019). Pengenalan Terumbu Karang, Sebagai Pondasi Utama Laut Kita. Unimal Press. Lhokseumawe. 